\title{
PENGGUNAAN PRINSIP KERJA SAMA DALAM PERCAKAPAN SINETRON DI SEBELAH ADA SURGA EPISODE 4
}

\author{
Astri $^{1}$, Ririn Setyorini*2 \\ 1,2Program Studi Pendidikan Bahasa dan Sastra Indonesia, Fakultas Keguruan dan Ilmu \\ Pendidikan, Universitas Peradaban \\ e-mail corresponden: *ririnsetyorini91@gmail.com
}

\begin{abstract}
Abstrak
Tujuan penelitian ini adalah untuk mengetahui penggunaan prinsip kerja sama pada percakapan dalam sinetron Di Sebelah Ada Surga Episode 4, khususnya untuk mengetahui dan mendriskripsikan maksim apa saja yang mengalami telah memenuhi serta latar belakang terjadinya prinsip kerja sama pada percakapan sinetron Di Sebelah Ada Surga Episode 4. Penelitian ini merupakan penelitian kualitatif. Data dalam penelitian adalah implikatur percakapan yang terdapat dalam tuturan pemain sinetron Di Sebelah Ada Surga Episode 4. Sumber data penelitian adalah sinetron Di Sebelah Ada Surga Episode 4, yang diproduksi oleh Starvision. Data penelitian diperoleh dengan teknik dokumentasi. Teknik ini diawali dengan menyimak seluruh percakapan dalam sinetron Di Sebelah Ada Surga Episode 4. Selanjutnya, peneliti mencatat seluruh data yang terkait, mengklasifikan serta mencatatnya kembali dalam kartu data. Teknik analisis data yang digunakan dalam penelitian ini adalah model analisis mengalir atau flow model analisis. Ada empat komponen dalam model analisis mengalir, yaitu pengumpulan data, reduksi data, penyajian data, dan penarikan simpulan atau verifikasi. Analisis data menunjukkan adanya penggunaan prinsip kerjasama maksim, diantaranya maksim kualitas, maksim cara, maksim kuantitas dan maksim relevansi
\end{abstract}

Kata Kunci: Prinsip kerja sama, sinetron, Di Sebelah Ada Surga, Pragmatik.

\begin{abstract}
The purpose of this study was to determine the use of the principle of cooperation in conversations in soap operas Di Sebelah Ada Surga Episode 4, especially to find out and describe what maxims who have fulfilled and the background of the cooperation principle in soap opera conversation Di Sebelah Ada Surga Episode 4. This research is a qualitative research. The data in this research are conversational implicature contained in the soap opera speech by Di Sebelah Ada Surga Episode 4. The source of research data is soap opera Di Sebelah Ada Surga Episode 4, produced by Starvision. Research data obtained by documentation techniques. This technique begins by listening to the entire conversation in the soap opera Di Sebelah Ada Surga Episode 4. Furthermore, researchers record all related data, classify and record it back on a data card. The data analysis technique used in this study is the flow analysis model. There are four components in the flow analysis model, namely data collection, data reduction, data presentation, and drawing conclusions or verification. Analysis of the data shows the use of the principle of cooperation maxim, including quality maxim, maxim way, maxim quantity and relevance maxim. Keywords: The principle of cooperation, soap operas, Di Sebelah Ada Surga, Pragmatics.
\end{abstract}

\section{PENDAHULUAN}

Prinsip kerjasama merupakan salah satu prinsip percakapan dalam ilmu pragmatik. Prinsip ini menekankan pada adanya upaya kerjasama yang terjalin antara penutur dan mitra tutur dalam sebuah percakapan. Kerjasama yang dimaksud berhubungan dengan tuturan yang diujarkan. Oleh karena itu, penutur selalu berusaha agar tuturannya relevan dengan konteks, jelas dan mudah 
dipahami, padat dan ringkas, dan selalu pada persoalan. Hal tersebut dirangkum dalam maksim-maksim yang terdapat dalam prinsip kerjasama.

Sinetron di Sebelah Ada Surga menceritakan tentang sebuah kisah permasalahan penggusuran tiga ruko milik Lilis, Solah, dan Jono. Pemilik ruko tersebut memiliki anak sebagai penerus ruko tersebut, di antaranya yaitu Uss, Gading, dan Andika. Selain ruko, ada salah satu musala yang ikut di gusur. Rencananya akan dibangun sebuah gedung besar milik seorang pengusaha kaya. Akan tetapi, pemilik tiga ruko tidak setuju dengan penggusuran tersebut. Begitu pula dengan beberapa warga setempat yang bersikukuh menolak penggusuran musala. Mereka beralasan karena ruko itu sudah menjadi satu-satunya mata pencaharian. Apabila ruko itu dijual dan digusur, mereka bingung akan mendapatkan uang dari mana. Sedangkan harga jual yang ditawarkan pengusaha kaya tersebut tidak sesuai dengan harga pada umumnya. Mereka berpikir hal itu hanya akan membuat rugi dan menyesal di kemudian hari.

Selanjutnya, beberapa warga yang sering menempati musala untuk beribadah itu menolak penggusuran. Hal tersebut dikarenakan musala itu tempat untuk melaksanakan ibadah secara berjamaah. Jika digusur, para warga setempat akan melaksanakan ibadah berjamaah di mana. Sedangkan musala itu adalah tempat ibadah paling dekat dengan para warga sekitar. Jika mencari musala yang lain, letaknya lebih jauh. Mereka berpikir musala itu tempat suci yang tidak sepatutnya untuk di gusur. Kemudian sudah seharusnya para warga sekitar berupaya mempertahankan agar musala itu tidak digusur.

Bahasa yang digunakan dalam sinetron tersebut mengandung penggunaan prinsip kerja sama. sinetron
Di Sebelah Ada Surga ini diproduksi oleh Starvision. Dalam penelitian ini episode yang diambil sebagai objek penelitian adalah episode 4. Sejalan dengan hal tersebut, penelitian ini bertujuan untuk (1) mendiskripskan maksim apa saja yang mengambang dalam percakapan Sinetron Di Sebelah Ada Surga Episode 4. (2) menjelaskan latar belakang terjadinya pengambangan pada Percakapan Sinetron Di Sebelah Ada Surga Episode 4. Penelitian ini juga dapat memberikan manfaat, antara lain (1) mengembangkan penelitian tentang prinsip kerja sama pada percakapan dalam film/sinetron, (2) memperdalam pemahaman tentang adanya prinsip kerja sama dalam perckapan sinetron $D i$ Sebelah Ada Surga Episode 4, (3) membantu pembaca untuk memahami prinsip kerja sama yang terjadi dalam percakapan sinetron Di Sebelah Ada Surga Episode 4.

\section{KAJIAN TEORI}

Bahasa berperan penting dalam kehidupan manusia sehari-hari. Manusia menggunakan bahasa untuk menyampaikan maksud mereka dalam berbagai kepentingan. Selain itu, keberadaan bahasa juga mempermudah manusia untuk saling berkomunikasi dan berinteraksi dengan manusia lainnya. Menurut peneliti [1] bahwa bahasa memiliki beberapa fungsi. Fungsi bahasa antara lain (1) untuk menyatakan ekspresi diri, (2) sebagai alat komunikasi, (3) sebagai alat untuk mengadakan integrasi dan adaptasi sosial dan (4) alat untuk mengadakan kontrol sosial.

Kehidupan manusia sebagai makhluk sosial menuntut penggunaan bahasa untuk berinteraksi dan berkomunikasi dengan sesama manusia. Komunikasi antara penutur dan lawan tutur dapat berhasil jika prinsip-prinsip kerja sama terpenuhi. Prinsip kerja sama 
ini menekankan pada empat maksim. Maksim yang dimaksud adalah: (a) maksim kualitas (Maxim of Quality), (b) maksim kuantitas (Maxim of Quantity), (c) maksim relevansi (Maxim of Relevance), dan (d) maksim cara (Maxim of Manner). Secara garis besar, prinsip kerja sama menekankan pada adanya upaya kerja sama yang terjalin antara penutur dan lawan tutur dalam percakapan yang sedang berlangsung.

Bentuk implikatur, sebagai tuturan yang mengandung maksud implisit, sangat memerlukan prinsip kerja sama tersebut. Tuturan yang mengandung makna implisit atau implikatur ini kadang-kadang tidak tampak pada penerapan maksim dalam prinsip kerja samanya. Jika percakapan berlangsung dengan baik, tidak terjadi kemacetan, maka tentunya terdapat penerapan prinsip kerja sama. Dalam percakapan sehari-hari, ditemukan beberapa fakta pelaksanaan prinsip kerja sama. Terdapat fakta adanya pematuhan dan pelanggaran prinsip kerja sama. Fenomena ini menunjukkan gejala penggunaan implikatur yang tidak sesuai dengan kaidahnya. Gejala yang I Dewa Putu Wijana menyebutnya sebagai bentuk penyimpangan. Namun, I Dewa Putu Wijana tidak menyebut implikatur yang tidak mengalami penyimpangan sebagai pematuhan. Berikut contoh pematuhan maksim prinsip kerja sama.

a. Ali : Kamu tinggal dimana?

b. Anto : Ah, rumah saya cuma gubuk.

Ali mengharapkan jawaban berupa nama tempat atau wilayah pemukiman karena ia menanyakan letak suatu tempat. Jawaban yang diterimanya justru bukan jawaban yang diharapkannya. Akan tetapi, dalam contoh di atas tidak tampak adanya pelanggaran maupun pematuhan maksim, yang terjadi adalah pengambangan. Pengambangan, semacam ada atau tidaknya pelanggaran maksim dalam percakapan yang bersangkutan.

Pemakaian bahasa dalam kehidupan dapat ditemukan dalam berbagai bidang, salah satunya dalam bidang hiburan khususnya film atau sinetron. Pada umumnya bahasa dalam sinetron menampilkan gambaran kehidupan. Di dalamnya terdapat percakapan-percakapan antartokoh. Percakapan-percakapan tersebut haruslah mempunyai keterkaitan agar penonton dapat memahami jalan cerita dari suatu film. Bahasa dalam film adakalanya berupa implikatur. Dengan implikatur, tuturan-turan dipandang lebih halus dan sopan. karena terkesan tidak to the point.

Menurut peneliti [2] implikatur "implicature" berasal dari kata kerja to imply sedangkan kata bendanya adalah implication. Kata kerja ini berasal dari bahasa latin plicare yang berarti to fold "melipat", sehingga untuk mengerti apa yang dilipat atau disimpan tersebut haruslah dilakukan dengan cara membukanya.

Memahami apa yang dimaksudkan oleh seorang penutur, lawan tutur harus selalu melakukan interpretasi pada tuturan-tuturannya. Peneliti [3] mengemukakan bahwa implikatur atau implikatur percakapan adalah adanya keterkaitan ujaran dari seorang penutur dan lawan tuturnya.

Namun, keterkaitan itu tidak tampak secara literal, tetapi dapat dipahami secara tersirat. Jelas bahwa kalimat-kalimat yang secara lahiriah kita lihat tidak berkaitan, tetapi bagi orang yang mengerti penggunaan bahasa itu dapat menangkap pesan yang ditangkap oleh pembicara, seperti tuturan (2) antara A seorang ibu rumah tangga dengan $\mathrm{B}$ seorang ibu rumah tangga lain.

(2) a : Bapak x tetangga kita yang baru itu mobilnya sering ganti-ganti ya. 
Jurnal SEMANTIKA, Volume 1, No. 01, Agustus 2019, p. 47-54

b : Tentu saja karena dia bekerja di kantor pajak.

Bisakah dipahami keterkaitan antara "sering ganti-ganti mobil" dengan "bekerja di kantor pajak?" Secara literal tidak bisa dipahami karena tidak disebutkan dalam pertuturan itu; tetapi secara tersirat bisa dipahami karena pada waktu sekarang kita tahu keadaan ekonomi seorang pegawai kantor pajak memang jauh lebih makmur dari pada yang tidak bekerja di kantor pajak [3].

Menurut peneliti [4] ada seperangkat asumsi yang melingkupi dan mengatur kegiatan percakapan sebagai suatu tindak berbahasa (speech $a c t$ ). Menurut analisisnya, perangkat asumsi yang memandu tindakan orang dalam percakapan itu adalah "prinsip kerjasama" (cooperative principle). Dalam melaksanakan "kerja sama" tindak percakapan, setiap penutur harus mematuhi empat maksim percakapan (maxim of conversation) yakni (1) maksim kuantitas, (2) maksim kualitas, (3) maksim relevansi, (4) maksim cara. Penjelasan keempat maksim tersebut adalah sebagai berikut:

1. Maksim Kuantitas (The Maxim of Quantity)

Maksim kuantitas menghendaki penutur untuk memberikan kontribusi yang secukupnya atau sebanyak informasi yang dibutuhkan. Berikut ini adalah contoh maksim kuantitas.

(4) a. Ali : Nama kamu siapa?

b. Evi : Nama saya Evi. Kelas tiga SD Cemara Dua. Rumah saya di Pasar Kliwon.

Bapak saya seorang polisi. Ibu saya seorang ibu rumah tangga. Agar percakapan di atas memenuhi prinsip kuantitas, Evi tidak perlu mengungkapkan dirinya secara lengkap karena Ali hanya menanyakan nama saja. Seharusnya Evi hanya menyebutkan namanya saja, tanpa mengungkapkan jawaban yang lain.

2. Maksim Kualitas (The Maxim of Quality)

Maksim kualitas menekankan tentang kewajiban penutur untuk mengatakan hal yang sebenarnya. Kontribusi penutur haruslah berisi kebenaran yang dapat dipertanggungjawabkan.

(5) a. Pak Guru : Dalam sehari terdapat berapa jam?

b. Siswa : 30 jam.

c. Pak Guru : Ya, selamat kamu telah dapat bonus tambahan enam jam ya.

Tuturan pak Guru (5c) Ya, selamat kamu telah dapat bonus tambahan enam jam ya dimaknai sebagai bantahan atas jawaban siswa yang salah. Harusnya siswa menjawab 24 jam. Dengan melihat tuturan pak guru, siswa akan berpikir bahwa tidak mungkin dalam sehari semalam terdapat tambahan jam.

3. Maksim Relevansi (The Maxim of Relevance)

Maksim relevansi mengharuskan peserta percakapan memberikan kontribusi yang sesuai atau relevan dengan pembicaraan. Agar lebih jelas, perhatikan contoh di bawah ini. (6) a. Tony : Pak, ada tabrakan motor lawan truk di pertigaan depan.

b. Bapak : Yang menang apa hadiahnya?

Menurut peneliti [5] bahwa Percakapan antara Tony dan bapaknya tentang peristiwa kecelakaan lalu lintas di pertigaan depan. Tabrakan terjadi antara sepeda motor lawan sebuah truk. Kecelakaan umumnya menimbulkan korban, baik korban luka maupun korban meninggal. Seharusnya bapak menanyakan apakah terjadi korban dari kecelakaan itu. Bukan 
Jurnal SEMANTIKA, Volume 1, No. 01, Agustus 2019, p. 47-54

menanggapinya dengan menanyakan hadiah bagi pemenang. Karena dalam kecelakaan tidak ada menang atau kalah.

\section{Maksim Pelaksanaan/ Cara (The} Maxim of Manner)

Maksim pelaksanaan mengharuskan setiap peserta percakapan berbicara secara langsung, tidak kabur, tidak taksa, tidak berlebih-lebihan, runtut, singkat-padat, dan secara tertipteratur.

(7) a. Tina : Masak Peru ibukotanya Lima. Banyak amat.

b. Andi : Bukan jumlahnya, tetapi namanya.

Peneliti [5] Dalam konteks percakapan di atas, yang dimaksud dengan Lima bukanlah berarti "nama bilangan', melainkan Lima adalah nama ibukota negara Peru. Dalam pragmatik tidak dikenal adanya ambiguitas. Ambigu harus dihindari dalam pragmatik.

Selain memahami maksimmaksim percakapan, implikatur juga membutuhkan beberapa perangkat untuk memahaminya. Perangkat ini akan akan membantu mitra tutur untuk memahami tuturan penutur. Diantara perangkat untuk memahami implikatur adalah (1) Praanggapan, (2) Inferensi, (3) Referen, dan (4) Interpretasi lokal dan analogi. Praanggapan memegang peranan penting dalam analisis wacana. Praanggapan yang tidak tepat dalam penggunaannya akan mengganggu koherensi atau keruntutan wacana. Kesalahan membuat praanggapan dapat mengakibatkan kesalahan dalam menerima implikatur. Sebaliknya, semakin tepat praanggapan yang digunakan,semakin komunikatif pula sebuah ujaran[6].

Inferensi atau penarikan simpulan menurut Gumperz adalah proses interpretasi yang ditentukan oleh situasi dan konteks percakapan. Dengan demikian inferensi tidak hanya ditentukan oleh mitra tutur, melainkan juga menghendaki konteks situasi. Penarikan inferensi akan sulit untuk dilakukan bila baik mitra tutur dan konteks situasi maupun salah satu di antara keduanya tidak sinkron. Ketidakjelasan konteks juga mempersulit pengambilan inferensi [6].

\section{METODE PENELITIAN}

Penelitian implikatur pada percakapan Sinetron Di Sebelah Ada Surga Episode 4 ini merupakan penelitian kualitatif. Data dalam penelitian ini adalah penggunaan prinsip kerja sama dalam percakapan yang terdapat dalam tuturan pemain sinetron Di Sebelah Ada Surga Episode 4. Adapun prinsip percakapan itu diketahui dengan mengenali adanya kerja sama tuturan penutur.

Sumber data penelitian ini adalah Sinetron Di Sebelah Ada Surga Episode 4. Karena terbatasnya penelitian dan waktu, peneliti hanya membatasi pengambilan data pada episode 4. Data penelitian diperoleh dengan menggunakan teknik dokumentasi. Jadi, penelitian ini dilakukan dengan cara melihat atau menyimak video atau tayang ulang Sinetron Di Sebelah Ada Surga Episode 4 dari internet.

Teknik ini diawali dengan cara menyimak seluruh percakapan dalam Sinetron Di Sebelah Ada Surga Episode 4. Selanjutnya, peneliti mencatat seluruh data yang terkait dan mengklasifikan data tersebut serta mencatat kembali dalam kartu data. Teknik analisis data yang digunakan dalam penelitian ini adalah model analisis mengalir atau flow model of analisis. Ada empat komponen dalam model analisis mengalir, yaitu pengumpulan data, reduksi data, 
Jurnal SEMANTIKA, Volume 1, No. 01, Agustus 2019, p. 47-54

penyajian data, dan penarikan simpulan atau verifikasi.

\section{HASIL DAN PEMBAHASAN}

Peneliti menemukan adanya penggunaan prinsip kerja sama dalam percakapan antar tokoh dalam Sinetron Di Sebelah Ada Surga Episode 4. Penggunaan prinsip kerja sama tuturan pada percakapan tersebut cukup banyak digunakan pada maksim- maksim tertentu. Berikut penjelasan dari penggunaan maksim kerja sama sebagai berikut.

\section{Maksim Kualitas}

Setiap percakapan menghendaki peserta tutur untuk memberikan kontribusi yang dapat dipertanggungjawabkan

kebenarannya. Maksim kualitas menghendaki penutur maupun mitra tutur mengatakan tuturan yang benar dan dapat dipertanggungjawabkan. Kontribusi yang diberikan hendaknya didasarkan pada bukti-bukti yang memadai. Percakapan antar pemain pada Sinetron Di Sebelah Ada Surga Episode 4 ini mengandung tuturan yang pada dasarnya memberikan kontribusi kebenaran. Percakapan ini menceritakan kejadian Solah yang menjenguk Lilis di rumah sakit. Kemudian Solah menanyakan kabar tentang kesehatan Lilis, seperti dalam percakapan berikut ini.

(1) a. Solah: Assalamualaikum ce.

b. Lilis: Waalaikumsalam.

c. Solah: Bagaimana sudah sehat ce?

d. Lilis: Alhamdulillah.

Percakapan pada data (1), tampak respon dari Lilis (1) b dan (1) d terlihat sudah memberikan kontribusi dalam percakapan dengan memberikan jawaban tersebut dan memenuhi maksim kerjasama.

\section{Maksim Cara}

Menurut Grice, setiap penutur yang terlibat dalam sebuah percakapan dapat dipastikan menaati prinsip kerja sama. Dalam mentaati prinsip kerja sama ini, penutur dapat menggunakan berbagai pilihan cara untuk menunjukkan kepatuhannya terhadap prinsip kerja sama. Salah satu pilihan yang dapat dilakukan adalah menggunakan cara atau teknik tertentu. Penutur dapat menggunakan kalimat langsung maupun tak langsung. Dalam percakapan Sinetron Di Sebelah Ada Surga Episode 4 terdapat penggunaan maksim cara. Percakapan ini menceritakan di salah satu ruangan kamar pasien yaitu Lilis sedang berbaring di tempat tidur, kemudian suster datang untuk memberikan informasi bahwa kata dokter, Lilis sudah boleh pulang. Percakapan tersebut adalah sebagai berikut.

(2) a. Lilis: Suster, ada apa yah?

b. Suster: Kata dokter, Ibu Lilis sudah bisa pulang hari ini. (Dengan memberi senyum ramah untuk meyakinkan).

Percakapan pada data (2), tampak respon dari Suster (2) b terlihat sudah memberikan kontribusi dalam percakapan dengan memberikan jawaban tersebut dan memenuhi prinsip kerjasama yaitu maksim cara. Suster memberikan cara dalam menyampaikan informasi dari dokter dengan sebuah senyuman untuk meyakinkan serta memperjelas bahwa $\mathrm{Bu}$ Lilis sudah dibolehkan untuk pulang.

\section{Maksim Relevansi}

Penutur dan mitra tutur selalu mengharapkan peserta percakapan mengucapkan tuturannya sesuai dengan konteks yang ada di sekitar percakapan itu. Tuturan yang sesuai 
dengan konteks akan memudahkan lawan tutur memahami apa yang dituturkan oleh penutur. Dalam percakapan Sinetron Di Sebelah Ada Surga Episode 4 terdapat penggunaan maksim relevansi. Percakapan ini menceritakan Uus, Gading, Andika, Pak Ustad, dan Rizki sedang dalam musyawarah membicarakan tentang perawatan musala. Kemudian tibatiba Uus dan Andika mendapat kabar bahwa orang tua mereka yang sedang di rawat di rumah sakit sudah boleh pulang. Percakapan tersebut adalah sebagai berikut.

(3) a. Uus: (Mendapat telepon dari rumah sakit). Alhamdulillah, Pak Ustad. Emak saya sudah bisa keluar dari rumah sakit.

b. Pak Ustad: Alhamdulillah.

c. Andika: Bisa barengan gitu. Tadi saya baru dapat sms, bapak saya juga sudah boleh keluar.

Percakapan pada data (3) tampak respon dari Uus (3) a dan Andika (3) c terlihat sudah memberikan kontribusi dalam percakapan dengan memberikan jawaban tersebut dan memenuhi prinsip kerjasama yaitu maksim relevansi. Dalam hal tersebut Uus dan Andika memberikan tuturan yang relevan sesuai dengan konteks dengan menyertai bukti berupa informasi melalui telepon yang diterima oleh Uus dan informasi melalui pesan atau sms yang diterima oleh Andika. Dengan demikian, percakapan tersebut telah memenuhi salah satu prinsip kerja sama yaitu maksim relevansi.

\section{Maksim Kuantitas}

Maksim kuantitas menghendaki penutur untuk memberikan kontribusi yang secukupnya atau sebanyak informasi yang dibutuhkan. Jadi, lawan tutur harus memberi informasi sesuai dengan yang dibutuhkan oleh penutur. Dalam percakapan Sinetron Di Sebelah Ada Surga Episode 4 terdapat penggunaan maksim kuantitas. Percakapan ini menceritakan tentang Andini dan Ida yang sedang membicarakan masalah ruko milik orang tua mereka yang akan di gusur.

(4) a. Andini: Eh Ida, kamu setuju gak sih kalau toko-toko kita digusur?

b. Ida: Hmm.., ih Ida teh nte setuju.

Percakapan pada data (4) tampak respon dari Ida (4) b terlihat sudah memberikan kontribusi dalam percakapan dengan memberikan jawaban tersebut dan memenuhi prinsip kerjasama yaitu maksim kuantitas. Jawaban Ida yang menggunakan campuran bahasa Sunda itu berarti bahwa Ida tidak setuju. Dengan jawaban tersebut menunjukkan adanya penggunaan prinsip kerja sama yaitu pada maksim kuantitas dengan jawaban Ida yang sesuai dengan yang dibutuhkan Andini sebagai penutur

\section{SIMPULAN}

Penggunaan prinsip kerja sama dalam percakapan Sinetron Di Sebelah Ada Surga Episode 4 ditemukan pada empat percakapan. Tuturan pada empat percakapan tersebut menunjukkan adanya pemenuhan prinsip kerja sama yaitu maksim kualitas, maksim cara, maksim relevansi, dan maksim kuantitas. Penggunaan prinsip kerja sama tersebut telah terpenuhi dalam beberapa percakapan yang sudah dianalisis dan dipaparkan. Dengan demikian, hal tersebut sudah menunjukkan bahwa dalam Sinetron $D i$ Sebelah Ada Surga Episode 4 terdapat penggunaan prinsip kerja sama yang baik antara penutur dan mitra tutur.

\section{REFERENCES}

[1] Sudaryono. 1993. Negasi dalam Bahasa Indonesia: Suatu Tinjauan 
Jurnal SEMANTIKA, Volume 1, No. 01, Agustus 2019, p. 47-54

Sintaksis dan Semantik. Jakarta: Pusat Bahasa

[2] Nadar, FX. 2008. Pragmatik dan Penelitian Pragmatik. Yogyakarta. Graha Ilmu

[3] Chaer, Abdul. 20I0. Kesantunan Berbahasa. Jakarta: Rineka Cipta.

[4] Grice, H.Paul. 1975. Logic and Conversation, dalam Cole and JL Morgan, Syntax and Semantics

[5] Wijana, I Dewa Putu. 1996. Dasardasar Pragmatik. Yogyakarta: Andi Yogyakarta. Available : http://bit.ly/fullepsSCTV

[6] Abdul Rani, Bustanul Arifin, Martutik. 2006. Analisis Wacana.

Malang: Bayumedia 